\title{
INDEX TO VOLUMES I. AND II.
}

\begin{abstract}
A
Address of the President. Isabel Hampton Robb

voL. PAGK Address of the President of the Third International Council of Nurses.

Isabel McIsaac ..................................., 1 Alumnæ Association, The Structural Elements of an. Clara D. Noyes ....ii., 358 Ambulance, The Brookline $\ldots \ldots \ldots \ldots \ldots \ldots \ldots \ldots \ldots \ldots \ldots \ldots \ldots \ldots, 6 \ldots \ldots$

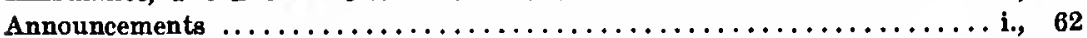
Antiseptic Solutions and Dusting Powders. Jessie Breeze ..........., 477
\end{abstract}

B

Baby, The Good. Helen MacMurchy, M.D. ..................., 346 "Backs and Mouths." Harriet Higbce ....................., 338 Bacteriology, The Relation of, to Preventive Medicine. John H. McCollom,

M.D. ............................... i., 40, 140, 218, 278

Bibliography, A, on Vacation Schools and Playgrounds for Children ......., 810 Blennorrhoea Neonatorum, The Management of. C. D. Wescott, M.D., and

B. Pusey, M.D. ............................., 635

Book Notices:

Vol.i. ....................................63, 603, 764

Vol. ii. ................205, 261, 364, 442, 514, 608, 682, 928, 1004

Boston City Hospital Nurses' Club. Emily 0. Boswall .............., 351

Boston Training-School, Early History of the. Mrs. Curtis and Miss

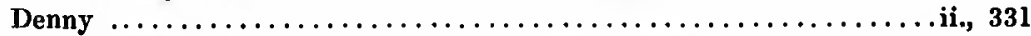

Brookline (Mass.) Isolation Hospital. H. Lincoln Chase, M.D. ........ i., 133 Bufialo General Hospital Training-School, History of. Lois Mastin Diehl. . i., 790

Canada, District Nursing in. Charlotte McCloud ................, 503 Cathartics and Hypnotics in Nervous and Mental Diseases. Walter Vose

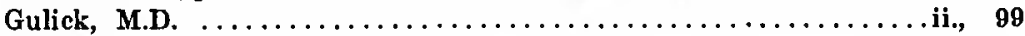

Catheterization, Dr. Howard Kelly's Method of ................, 798

Changes in the Army Nurse Corps:

Vol. i. ...........156, 245, 313, 390, 457, 529, 609, 693, 774, 850, 938

Vol. ii. . . . . . . . ...61, 139, 229, 291, 396, 477, 548, 633, 717, 960, 1033

Child's Body, Disinfection of a. Louise C. Brent ..............., 574 
Children, Some Practical Hints as to the Management of. Christie Fraser i., 131

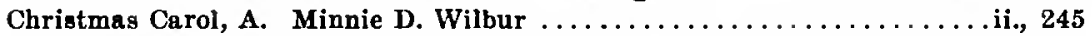
Christmas Days, Some, in Army Hospitals. Dita H. Kinney ............, 155 Christmas in a Hospital. Florence M. Angell ..................., 169 Cleanliness in Small Things. Helen C. Jenks .................., 468 Colorado Springs, Invalid Life in. Margaret Eastburn .............., 647 Constipation, Massage for. Kate W. Williams ................, 713 Consumers' League, The. Florence Kelley ...................., 046 Contagion, Early Struggles with. Ellen La Motte $\ldots \ldots \ldots \ldots \ldots \ldots \ldots$ i., 541 Convalescence. Ruth Brewster Sherman ..................., 801 Cow's Milk, Practical Home Modification of. Mary Steele Ewing ........ i., 493 Crippled Children's School, The. Agnes Curtis ................., 427 "Cry" of a Child, The. E. Stanley Ryerson .................., 267 Cuba, The Establishment of Schools for Nurses in. M. Eugenie Hibbard..ii., 985

D

Dead, Reverent Care of the. Charlotte M. Perry ................ii., 335 Deaf Children, A Word to the Mothers of $\ldots \ldots \ldots \ldots \ldots \ldots \ldots \ldots \ldots$., 715 Denmark, Nursing in. Charlotte Norrie ...................., 183 Diet-Lists for Private Duty Nurses, Convenient .................., 119 Diphtheria. James B. Herrick, M.D. ..................., 332, 407 Disinfection and Protection in Our Schools. Helen Scott Hay ......... i., 502 Disinfection, Methods of, by Health Department of New York City ....... i., 540 Disinfection, Municipal, in Berlin. Rebecea Shatz ................, 554 Disinfection of Sick-Rooms and Their Contents. Mary M. Riddle ....... i., 508 District Nursing, Some Special Features of. A. M. Carr ............ i., 253 Drugs, New .................................., 429 Drugs: Their Use and Abuse. William Schleif, M.D. ...... i., 580, 737; ii., 29

$\mathbf{E}$

Economics, Hospital. Isabel Hampton Robb ..............., 29, 130 Editor, The ........., 64, 166, 249, 316, 393, 459, 533, 612, 696, 776, 854, 941 Editorial Comment ....ii., 71, 150, 238, 290, 407, 487, 562, 043, 727, 974, 1044 Editor's Miscellany:

Vol. i. ..........57, 160, 241, 311, 387, 451, 525, 605, 690, 766, 845

Vol. ii. . ...........67, 143, 233, 404, 485, 560, 639, 725, 970, 1042

Education of Nurses, The Preliminary. M. Adelaide Nutting . . . . . . i., 416 Egypt, Travelling with a Patient in. Mary Cloud Bean .............., 699 England, District Nursing in, Origin, Growth, and Present Status. Amy

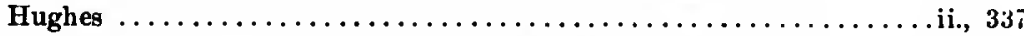

Enteroclysis and Colonic Flushing. Anna A. Davidson ............, 799 Entrance Examination of Nurses, The. Harriet Camp Lounsbery ....... ii., 071 Ethics in Nursing. Isabel MeIsaac ......................., 483 Exclusion Effective? Is. L. L. Dock $\ldots \ldots \ldots \ldots \ldots \ldots \ldots \ldots \ldots \ldots$ i., 470 Experiment, A Successful $\ldots \ldots \ldots \ldots \ldots \ldots \ldots \ldots \ldots \ldots \ldots \ldots \ldots \ldots \ldots \ldots \ldots$., 729 
$\mathbf{F}$

VOL. PAGE

Fads: Their Value to Nurses. Marthạ M. Russell ..................., 355

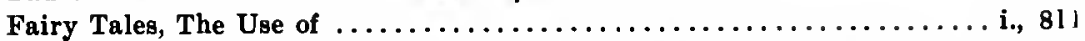

Feeding Children, Experiments in Methods of. Margaret M. Tooker .....ii., 105

Feeding of Children, The. Joseph Roby, A.B., M.D. ......., 412, 486, 575, 644

Fiji, Nursing in. May C. Anderson ........................ 1029

Finsen Light Treatment for Lupus, The. Eveline Dickinson ..........ii., 658

Fire, What to Do in Case of. Charles O. Boswell, M.D. ..............., 194 Floating Hospitals, Our. Charlotte Mandeville Perry .............., 104 Foreign Department:

Vol. i. ............51, 151, 238, 306, 381, 444, 519, 598, 685, 758, 840

Vol. ii. . ...........58, 132, 222, 288, 389, 466, 545, 629, 709, 956, 1027

France, Nursing in. Anna Hamilton ....................., 132

Fresh Air and Sunshine. Olive Williams ..................., 339

Garfield Alumnæ, Work of the. R. Mildred Purman .............., 216

General Reading, Value of, for Private Duty Nurses. Edith A. Draper . . . i., 205

Glasgow's Stately New Hospital. Mary C. Norris .................i., 673

Gleanings from the Medical Press,

ii., 108, 207, 262, 366, 444, 516, 610, 685, 030, 1006

Graduate Nurse of To.day, The Opportunity and Responsibility of :

First Paper. Katherine De Witt ....................., 75

Second Paper. Linda Richards ....................., 78

Graduate Nurses' Association of Cleveland, Objects of. M. Helena

McMillan, B.A. ................................, 187

Graduates, A Word to the. Anna A. Davidson ................., 42

Greece, Progress of Women in Modern. Dr. Achilles Rose ........... i., 779

Guild of St. Barnabas, The .........ii., 270, 371, 450, 525, 616, 691, 941, 1018

Gynæcological Operations, Forced Water in. Louella B. Warren ........., 198

$\mathbf{H}$

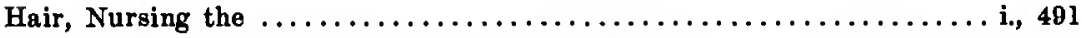

Hamburg State Hospitals, The Nursing Association of. Hedwig von

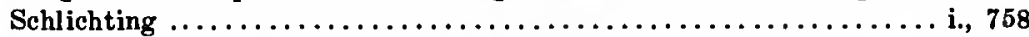

Head Nurse, The Duties of the. M. Helena McMillan, B.A. ............, 640

Higher Education of Trained Nurses. Mrs. Bedford-Fenwick ..........i., 4

Hospital and Training-School Items:

Vol. i. ..........45, 146, 227, 285, 363, 431, 498, 583, 685, 739, 820

Vol. ii. .........44, 114, $210,265,369,447,519,613,688,934,1013$

Hospital Economics-1902-1903, Special Course in ............... $\mathbf{- 5 9 6 , 6 7 5}$

Hospital Economics, The Special Course in .................., 800

Hospital, In. M. E. R. ..............................., 8

Hospital, The Modern: Its Value to Patient and Physician. Edward B.

Angell, M.D. .................................... 703

House-Fly, Transmission of Pathogenic Germs by the. Jacolyn Manning,

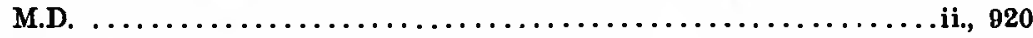

Hygiene of the Household, The. Eveleen Harrison ........ii., 494, 588, 688, 917 


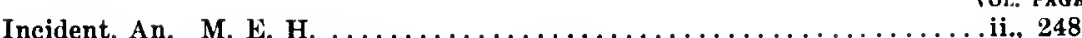

Indian Army Nursing Service, The. A. Arkle ................ 052

Industrial Problem, Committee of the General Fcderation of Women's

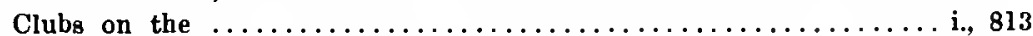

Infant Feeding. W. B. Thistle, M.D. ...................., 22

Infants, The Feeding of. John Lovett Morse, A.M., M.D. ............., 14

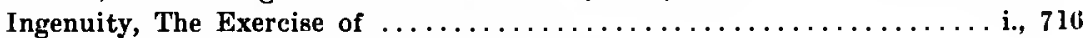

Insane, Care of the:

I. Asylum Nursing. Mrs. Chapman ..................., 164

II. Nursing of the Insane. S. Louise Laird ..............., 170

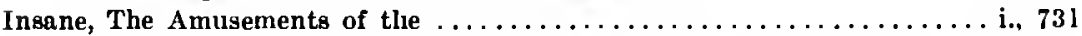

Insane, Women in the Care of the. Julia C. Lathrop ................., 430

Insects, Role of, in the Propagation of Disease. John H. McCollon, M.D. ii., 181

Inspection, Medical, of Schools in Boston. Charles G. Dewey, M.D. . . . . i., 650

International Council of Nurses. Lavinia L. Dock .............. i., 114

International Council of Nurses, The. Ethel Gordon Fenwick .........., 785

Ivy Poisoning, Report of a Case. Ruth Brewster Sherman ............, 660

J

Jane Club of Hull House. Eliza P. Whitcombe .................ii., 86

Japan, Nursing Progress in. Linda Richards ..................., 491

$\mathbf{K}$

Kindergarten Hour, The. Mary Isabel Hamilton $\ldots \ldots \ldots \ldots \ldots \ldots \ldots$ i., 578

Kinney, Mrs. Dita H. ............................., 403

Kris-Kringle, The Delightful Farce of. H. S. Hutchison, M.D. ........., 341

$\mathbf{L}$

Laundry of University of Pennsylvania Hospital, New. A. C. Abbott.

M.D. ................................. 224, 282, 359

Laundry, Suggestions for a Modern Hospital. George H. M. Rowe, M.D. . . i., 656

Law, What we may Expect from the. Lavinia L. Dock .............., 8 Leaves from the Note-Book of a Bellevue Nurse,

ii., $249,351,435,498,593,925,999$

Letter, An Open, with Answer ........................., 480

Letters to the Editor ......ii., 62, 142, 231, 292, 398, 470, 550, 635, 720, 962, 1038

London Public School Nurse, The. Honnor Morten ................, 274

\section{M}

Maine, With the, to South Africa. M. Eugenie Hibbard ..... i., 1, 319, 395, 615 Massachusetts General Hospital Training-School, Changes in Curriculum

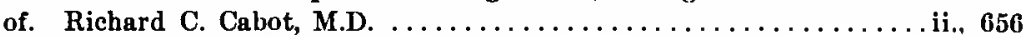


Massage in Infantile Paralysis. T. Ambrose Stanton, vol.. PaGr. Massage of the Scalp, Method of. Kate W. Williams ................ 211 Massage, The Teaching of, to Pupils in Training-Schools, Helen Conkling

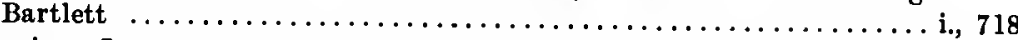

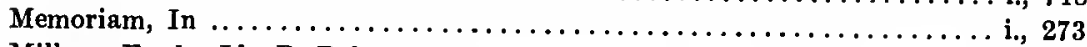

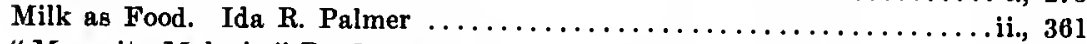

“Mosquito Malaria,” Dr. Manson and. Helen MacMurchy, M.D. ....... i., 202

\section{$\mathbf{N}$}

Normal Salt Solution. Idora Rose . . . . . . . . . . . . . . . . . i., 262 North Carolina, Western, as a Health Resort. Mary P. Laxton ............, 893 Nurses and Their Education. S. Weir Mitchell, M.D. . . . . . . . . . . ii., 890 Nurses' Associated Alumnæo of the United States, Proceedings of the Third Annual Convention:

Address of Welcome by Mrs. Cadwalader Jones . . . . . . . . . . i., 71 Report of Executive Committee $\ldots \ldots \ldots \ldots \ldots \ldots \ldots \ldots \ldots \ldots \ldots$ i., 74 Treasurer's Report $\ldots \ldots \ldots \ldots \ldots \ldots \ldots \ldots \ldots \ldots \ldots \ldots \ldots \ldots \ldots \ldots \ldots$ i., 75

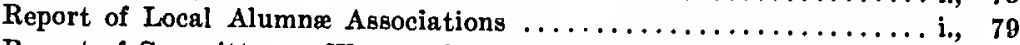
Report of Committee on Ways and Means of Publishing a Magazine .. i., 80 Report of Educational Committee....................., 83 Report of Committee on Division of Expenses $\ldots \ldots \ldots \ldots \ldots \ldots \ldots \ldots$., 84

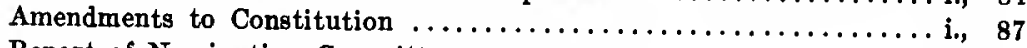

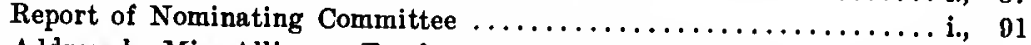
Address by Miss Alline on Teachers Course of Study $\ldots \ldots \ldots \ldots \ldots \ldots$., 92 Army Nursing Bill $\ldots \ldots \ldots \ldots \ldots \ldots \ldots \ldots \ldots \ldots \ldots \ldots \ldots \ldots \ldots \ldots$ i., 93

Nurses' Associated Alumna of the United States, Proceedings of the Fourth Annual Convention:

President's Address ..........................ii,, 307

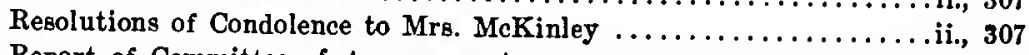

Report of Committee of Arrangements .................., 307

Report of Executive Committee $\ldots \ldots \ldots \ldots \ldots \ldots \ldots \ldots \ldots \ldots \ldots$. 308

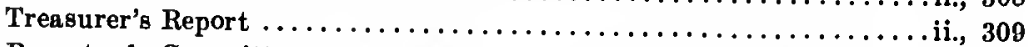

Report of Committee on Affiliation of Superintendents' Society .....ii., 313 Report of Delegate to National Council of Women .............., 314

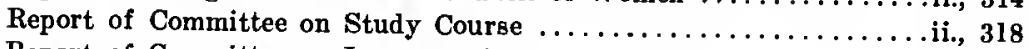

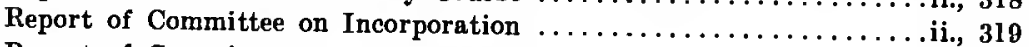

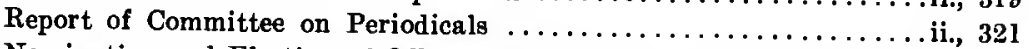
Nomination and Election of Officers $\ldots \ldots \ldots \ldots \ldots \ldots \ldots \ldots \ldots \ldots \ldots \ldots \ldots \ldots$., 327

Nurses' Associated Alumno of the United States, Proceedings of the Fifth

Annual Convention. Leading papers:

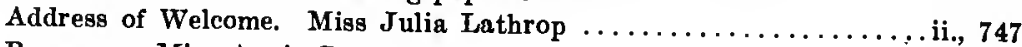

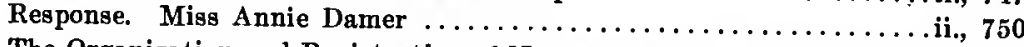
The Organization and Registration of Nurses. Mrs. Bedford-Fenwick ii., 771

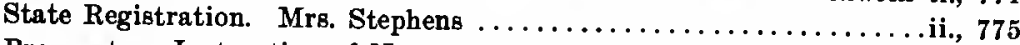
Preparatory Instruction of Nurses. Mrs. Strong . . . . . . . . . . . . $79 ., 7$ The Education of Nurses. Mrs. Mary Adelaide Nutting . . . . . . . . ii., 799

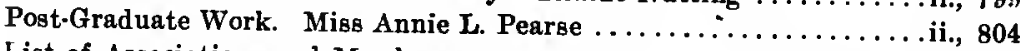
List of Associations and Members $\ldots \ldots \ldots \ldots \ldots \ldots \ldots \ldots \ldots \ldots ., 810$ 
Nurses in Asylums. S. L. Laird ........................, 515

Nurses' Settlement. Lillian D. Wald ......................, 39

Nurses' Settlement in New York, The. Lillian D. Wald ............. 567

Nursing, Education in. Mrs. Strong ....................., 344

Nursing, Specialties in. Katherine De Witt $\ldots \ldots \ldots \ldots \ldots \ldots \ldots \ldots$., 14

Nursing, Visiting. Eliza J. Moore ......................, 17

Nursing Work, A Demonstration of. Sara Anice Bowen ........... 808

Obstetrical Emergencies. Henry D. Fry, M.D. .............., 107, 194

Obstetric Nursing, Preliminaries of. Mary L. Keith .............., 257

Official Reports of Societies:

Vol. i. ...............294, 373, 437, 507, 588, 675, 747, 829, 918

Vol. ii. ...........49, 121, 214, 278, 377, 456, 534, 621, 609, 731, 947, 1021

Openings for Nurses. Elizabeth Robinson Scovil ................, 439

Operating-Room Nurse, Duties of. Martha Luce .............., 404, 471

Orange Visiting Nurses' Settlement, The. Margaret H. Pierson .........., 276

Orthopædic Surgical Cases, Nursing Care of. Eleanor Wharton Wood .....ii, 425

Outfit of the Private Duty Nurse. Helen S. Hay .................., 264

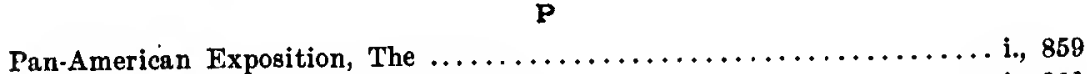

Foreign Delegates and Organizations $\ldots \ldots \ldots \ldots \ldots \ldots \ldots \ldots \ldots \ldots$ i., 861

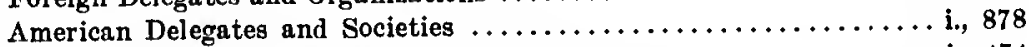

Patient, Travelling with a. Mary Cloud Bean .................., 474

Play-Schools, Work for Nurses in. Mary Boyle O'Reilly ............., 37

Post-Graduate Work, The Necessity for the Development of. Persis

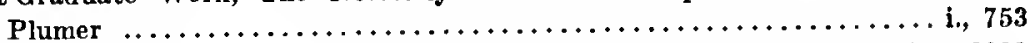

Practical Hints .............ii., 111, 277, 374, 453, 529, 619, 695, 945, 1019

Preliminary Training in the London Hospital. Eva C. E. Luckes ....... i., 270

Private Nursing. Margaret L. Rogers ....................., 82

Private Nursing from a Nurse's Point of View. Josephine Hill ......... i., 129

Professional Practice, Examinations for Admission to, in New York.

Henry L. Taylor, Ph.D. ............................ 582

Prophylaxis of Poverty. Delia Knight ...................., 40

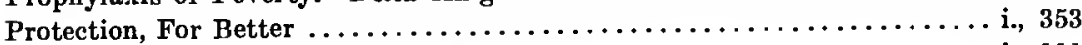

Psychic Factor, The Nurse and the. Delia Knight $\ldots \ldots \ldots \ldots \ldots \ldots$.., 111

Q

Queen's Reception of American Nurses and Doctors, The. M. Eugénie

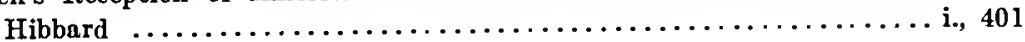

$\mathbf{R}$

Really a Profession? Is Nursing. A. Worcester, M.D. ................, 908 Reduction of Temperature in Febrile Cases, Means Used for. Sara M.

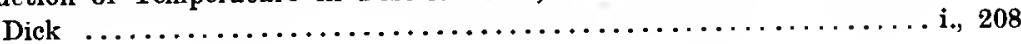


vol. PAGE

Reform and Protective Work, Nursing Profession in. Linda Richards ....ii., 591

Retrospect and a Forecast, A. Catharine J. Wood ..............., 159

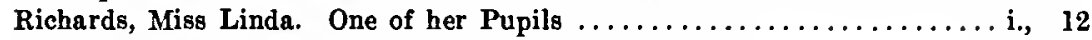

Richmond, Va., Nurses' Settlement in. Mamie J. Minor . . . . . . . . . . ii., 996

Robb, Isabel Hampton. Edith A. Draper ...................i., 243

Russell, Address of Dean ............................, 172

\section{$\mathbf{S}$}

Sanitary Inspectors, Nurses as. Johanna von Wagner ............., 489 Sanitation of Public Institutions. Charles F. Wingate $\ldots \ldots \ldots \ldots \ldots \ldots \ldots$., 816 Scarlet-Fever: Isolation and Disinfection. Frances E. Morley ........ i., 558 School for Nurses, Preparatory. Annic M. Shiels . . . . . . . . . . . . . . .., 424 Small Hospital and the Training-School, Bertha Mayne ............, 260 Social Settlements, Nurses'. Lillian D. Wald ..................., 682 Sophiahemmet in Stockholm, The. Lillian D. Wald .............., 180 South Africa, History of Registration in. Margaret Breay ..........i., 710 Spinal Cocainization. Beatrice S. Monteith .................., 796 Splints, The Application of, to Growing Children. E. C. Ashton, M.D.,

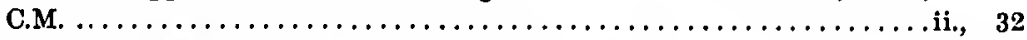
Sponges, Counting of, in Abdominal Surgery. Mary E. Smith .........ii., 200 State Registration for Nurses. L. L. Dock ...................ii., 979

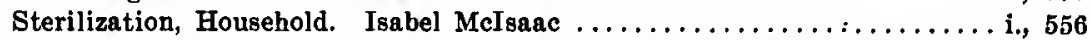
Study, Course of, Subjects Selected by Committee on. Frances A. Stone . . i., 213 Superintendent, The Problem of the. Elizabeth Robinson Scovil .........i., 36 Surgical Case, The Treatment and Nursing of a, in $1569 \ldots \ldots \ldots \ldots \ldots$. . . . 438 Surgical Nursing, Formuls Used in. Charles G. Cumston, M.D. ....... i., 200 Syphilis, The Relation of, to the Nursing Profession. L. B. Baldwin, M.D. ii., 103

Teeth, The Care of Children's. A. E. Webster, M.D., D.D.S. . . . . . . . . . i., 722 Tenement-House Commission, Extracts from Report of New York. L. L.

Dock . . . . . . . . . . . . . . . . . . . . .

Tenement-House Inspection. Yohanna von Wagner ..............i., 508

Trained Nurse, The Evolution of the. E. D. Ferguson, M.D. . . . i., 463, 535, 620 Trained Nursing, How Began in America :

At the New England Hospital. Linda Richards . . . . . . . . . .i., 88

History of the Reform in Nursing in Bellevue Hospital. L. L. Dock ii., 88 Training-Schools, The Relations of, to Hospital Administration. Mary

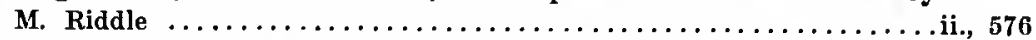

Trip Abroad, A Working Woman's. Elise H. Lampe . . . . . . . . . . i., 329

Tuberculosis, Baltimore's Work in. Ruth Brewster Sherman .........., 626

Tuberculosis, Pulmonary, Recent Discussions of. Delia Knight ........ i., 732

Tuberculosis, The Discussion on. Ruth Brewster Sherman .........ii., 24

$\mathbf{U}$

Uniform, Unprofessional Display of. Clara Sanford Lockwood .........ii., 203 
$\boldsymbol{V}$

VOL. PAFiE

Vaceination, Statutes of Massachusetts Concerning ............., 735

Verses. Ruth Brewster Sherman ......................., 107

Visiting Nurse Work in America, History of. Harriet Fulmer.........ii., 411

Visiting Nursing in New York. Merle Carhart ................, 836

$\mathbf{w}$

Wilhelmina Hospital, Holland, The Training of Nurses in. Mej L.

Kruysse $\ldots \ldots \ldots \ldots \ldots \ldots \ldots \ldots \ldots \ldots \ldots \ldots \ldots \ldots \ldots \ldots \ldots \ldots \ldots \ldots \ldots \ldots$

Women on Hospital Boards. Isabel Hampton Robb . . . . . . . . . . ii., 252

Women, Work of, on Hospital Boards. Louisa Stevenson ............ 325

Worth While? Was it. Mary Reynolds ...................., 991 